STIMULATION OF THE GERBIL'S GUSTATORY RECEPTORS BY DISACCHARIDES

WILLIAM JAKINOVICH, JR *

Department of Zoologv, The Uniersitv of Michigan, Ann Arbot, Mich 48104 (USA)

(Accepted November 29th, 1975)

SUMMARY

The gustatory responses from the chorda tympanı nerve of the Mongolıan gerbil, Merlones unguaculatus, were tested with 13 disaccharides Sucrose was the most stımulatory sugar

The ability of fructosyl glycosides to stımulate may depend upon the linkage batween fructose and the glycoside Disaccharides possessing $1 \rightarrow 3,1 \rightarrow 4$, or $1 \rightarrow 6$ lınkages were poor stımulı compared to sucrose which has a $1 \rightarrow 2$ linkage Glucopyranosyl disaccharides with an $\alpha$-lınkage were better stımulı than the $\beta$-anomers, while galactopyranosyl disaccharides possessing a $\beta$-linkage were better than their $\alpha$-anomers

\title{
INI RODUCTION
}

There have been several attempts to account for the sweetness of structurally diveıse sweet chemicals ${ }^{9,25,28,3137}$ Electrophysiological recordings from single receptor cells ${ }^{26,31}$ or primary afferent fibers ${ }^{12} 1415,29,32,33$ in mammals have not found receptor cells or taste nerve fibers which respond more or less exclusively to chemicals that are sweet to humans Biochemical investigations with sugar-binding proteun preparatıons $s^{5,6,20}$ of tongue epithelıum suffer from a scarcity of physiological data from which inferences concerning the identity of sweet receptor sites can be drawn

Sugar-receptor site specificity was examined by analyzing electrophysiological responses of the gerbıl's chorda tympanı nerve to disaccharıdes Both $\alpha$ and $\beta$ anomers such as maltose and cellobiose, melibiose and lactose, and their chemically reduced derivatives, the alditols, were compared since anomeric linkages play an important role in determining the effectiveness of a disaccharıde as a gustatory stımulant ${ }^{7} 16$ The alditol disaccharides were synthesized from their parent sugars to see if sub-

* Present address The Procter and Gamble Company, Miamı Valley Laborator'es, P O Box 39174, Cincinnat, Ohio 45247, U S A 
stantal changes in the molecule would have an eflect on the stimulatory ability in a disaccharide Subsequent paper will deal with monosacchaldes and polyol

\section{MATERIALS AND METHODS}

Animals

The Mongolian geibil, Meriones angutculatus, was used because of its demonstrated sensitivity to suciose?2 21 Animals used in these experiments were obtaned from a closed colony ( $\mathrm{J}$ Hasendu, Northville, Mich) and were less than 1-yedl-old

\section{Sugars}

The sugars were oblaned from Pfanstiehl Laboratories, Waukegan. III Sigma Chemical Co, St Lours, Mo, or were synthesized Cellobiltol, latitol maltitol and melibitol were prepared by the reduction of the respective disaccharide with $\mathrm{NaBH}_{4} \mathrm{Na}^{+}$was removed with Amberlite IR-120 (H') followed by Amberlite IR-45 $\left(\mathrm{OH}^{-}\right)$to remove the borate ion The purity of the disaccharide alditols wal evaluated by thin-layer chromatography on activated Silica Gel G codted plates uning $n$-butanol-acetic acid-ethyl acetate-water $\left(\begin{array}{llll}9 & 6 & 3 & 2\end{array}\right)$ as the solvent Components 4 ha visualized by sprayng with $50^{\circ}{ }_{\circ}$ ( $\left(v_{i}^{\prime} v\right)$ ethanol-sulfuric acid followed by charing in an oven at $120 \mathrm{C}$

\section{Taste solutions}

All compounds were dissolved in distilled water and were stored at 2 C for 0-14 days before use Solutions of reducing sugals were prepared a day before use and were allowed to reach mutarotational equilibrium at room temperature Solutions of $\beta$-lactose neie used immediately after preparation

\section{Electrophystological}

The animal was anesthetized with an intramuscular or intraperitoneal injection of sodium pentobarbical ( $35 \mathrm{mg} / \mathrm{kg}$ ) One-half the initial dose was given at $30-\mathrm{mm}$ intervals untıl the animal was completely anesthetized During the experiment dosis of similar magnitude were given to maintain the level of anesthesid

The procedures for exposing the chorda tympani net ve in the middle edr and for chemically stimulating the tongue have been described 22,21 Electrical activity $w$ as recoided by touching the nerve with a nichrome electrode which was led to a diffe-ential amplifier (Grass P-511) The integrated discharge of the whole chorda tympanı nerve was used because it iepresents a summation of activity from many tecepto* cells $^{23}$ A response was defined as the difference between the integrated spontaneous activity and the greatest integrated potential elicited by a given solution applied to the tongue The integrator (Grass Model No 73PA) tıme constant wds set at $05 \mathrm{sec}$, full wave rectification An indifferent electrode was placed on a nearby piece of moist tissue within the duditory bulla

The temperatures of the distilled water rinse and the taste solution were identikal $(25+1 \mathrm{C})$ Solutions were presented in increasing series of approximately $05 \mathrm{log}$ molar concentration steps ( $\mathrm{g}, 00001 \mathrm{M}, 00003 \mathrm{M}, 0001 \mathrm{M} 001 \mathrm{M,03}$ H) 
Responses were calculated from at least two complete series of test solutions per anımal A standard solution (03 $M$ sucrose) was presented frequently between test solutions Whenever the standard $03 M$ sucrose solutions elicited tesponses that valed more than $\succeq 10^{\circ}$ o all interjacent "esponses were rejected

\section{Concentiation-iesponse curves}

All concentrations of sugdrs are expressed in molarity and plotted on a logarithmic scale Each animal was presented with a concentration series of sucrose which allowed computation of the response of any other sugar as a percentage of the maximum (saturation level) sucrose response In the 5 animals, out of 59 , in which the maximum response was not attained within the sucrose concentration range tested, the response to $10 \mathrm{M}$ sucrose was considered $100^{\circ}$ "

The effectiveness of sugars is indicated by their $\mathrm{CR}_{5 / 2} \mathrm{~S}$ This value, the concent'ation that evokes a response $50^{\circ}$ "of maximum, is similar but not identical to the dissociation constant of Beidler's taste model ${ }^{3}$ Unlike the dissociation constant of Beidler's taste theory which is measured from the reciprocal plot, the $\mathrm{CR}_{50} 1 \mathrm{~s} 110 \mathrm{ot}$ linked to theoretical assumptions about the nature of sugar-receptor interactions

$\mathrm{CR}_{50} \mathrm{~S}$ were compared in those sugars which were sufficiently soluble to permit a miximum 'esponse to be reached The dissociation constant, obtained from the recipiozal plot, was used as the index of telitive stımulating effectiveness for those sugars that were too viscous on insoluble to use at high concentrations The dissociation constant was calculated from the summated iesponse data which reflects the interaction of the stimulus, $S$, upon the receptor sites, $R$, as represented by the following equation

$$
\mathrm{S}+\mathrm{R} \leftrightharpoons \mathrm{SR}
$$

The dissociation constant, $K_{u}$, is equal to the reciprocal of the association constant $\left(K_{t \prime}\right)$ of Baidler's tuste theory ${ }^{3}$

$$
k_{d}-\frac{[\mathrm{S}]}{[\mathrm{SR}]}[\mathrm{R}]
$$

Assuming that (a) the response (Resp) measured was linearly related to the number of stimulus molecules bound $(\operatorname{Resp} \propto[\mathrm{SR}])$ and (b) at a high concentration of $S$ the maximal response (Resp max) was reached and then

$$
\frac{\operatorname{Resp}}{\operatorname{Resp} \max }=\frac{\text { sites filled }}{\text { total sites }}=-\frac{[\mathrm{SR}]}{[\mathrm{R}] \frac{-}{+}[\mathrm{SR}]}
$$

Then by substitution of equation (2) into equation (3)

$$
\frac{\operatorname{Resp}}{\operatorname{Resp} \max }=-\frac{1}{1+\frac{K_{d}}{[\mathrm{~S}]}}
$$


By rearrangement of equation 4 we get

$$
\begin{array}{ccc}
{[S]} & {[S]} & \Lambda_{l} \\
\operatorname{Resp} & \operatorname{Resp} & -\operatorname{Resp}_{\max }
\end{array}
$$

Since $K_{a}=1 / K_{d}$ this equation is Beidler's taste equation ${ }^{3}$ At Resp/Resp $\max -12$ it follows that $\mathrm{CR}_{50}-K_{d l} \quad[\mathrm{~S}]=1 / K_{a}$ If more than one stimulus molecule combined with a receptor site then

$$
\mathrm{nS}: \mathrm{R} \rightleftharpoons \mathrm{RS}_{\mathrm{n}}
$$

and the response would be proportional to the amount of $\mathrm{RS}_{\mathrm{n}}$ formed Equation 4 would become

$$
\begin{array}{cc}
\operatorname{Resp} & 1 \\
\operatorname{Resp} \max & 1+\frac{K_{l l}}{[\mathrm{~S}]^{\mathrm{n}}}
\end{array}
$$

By rearranging equation 7 and taking the $\log$ we get

$$
\log \underset{\operatorname{Resp} \operatorname{Rax}-\operatorname{Resp}}{\operatorname{Resp}}=\mathrm{n} \log [\mathrm{S}]-\log K_{d}
$$

This is identical to the Hill plot ${ }^{21}$ A similar equation was used by Tateda and Hida$\mathrm{ka}^{36}$ for the analysis of neural response by a rat to glycine

RESULTS

When any effective chemical was flowed onto the tongue there was an initial rapid rise of neural activity which was dependent upon concentration Fig 1 is a typical series of recordıngs A slight upward deflectıon of the baseline at threshold can be seen at $0003 M$ The weakest effective stimulus in the concentration series was defined as the threshold concentration Sometimes at high concentrations, shown in Fig 1 for $03 \mathrm{M}$ and $10 \mathrm{M}$, after the neural discharge reached its initial peak it declined and then recovered to its maximum level The dip phenomenon only occurred at high concentrations of sugars The second peak was not a water rinse response since it occurred before the water rinse Generally the response declined gradually after the initial response Upon rinsing with distilled water the discharge dropped rapidly to the prestimulation level 'Off' discharges of the type seen with divalent cation stimulation'4 were rarely observed with the disaccharides

On semilogarithmic coordinates, the concentration-response function for sugars was always sigmoidal (Fig 2) Of all the disaccharides tested, sucrose was the best stımulus (Table I), it gave the greatest response, had the lowest $\mathrm{CR}_{50}$ and was detected at the lowest concentration All other sugars tested had a threshold 10-30 times higher than sucrose 

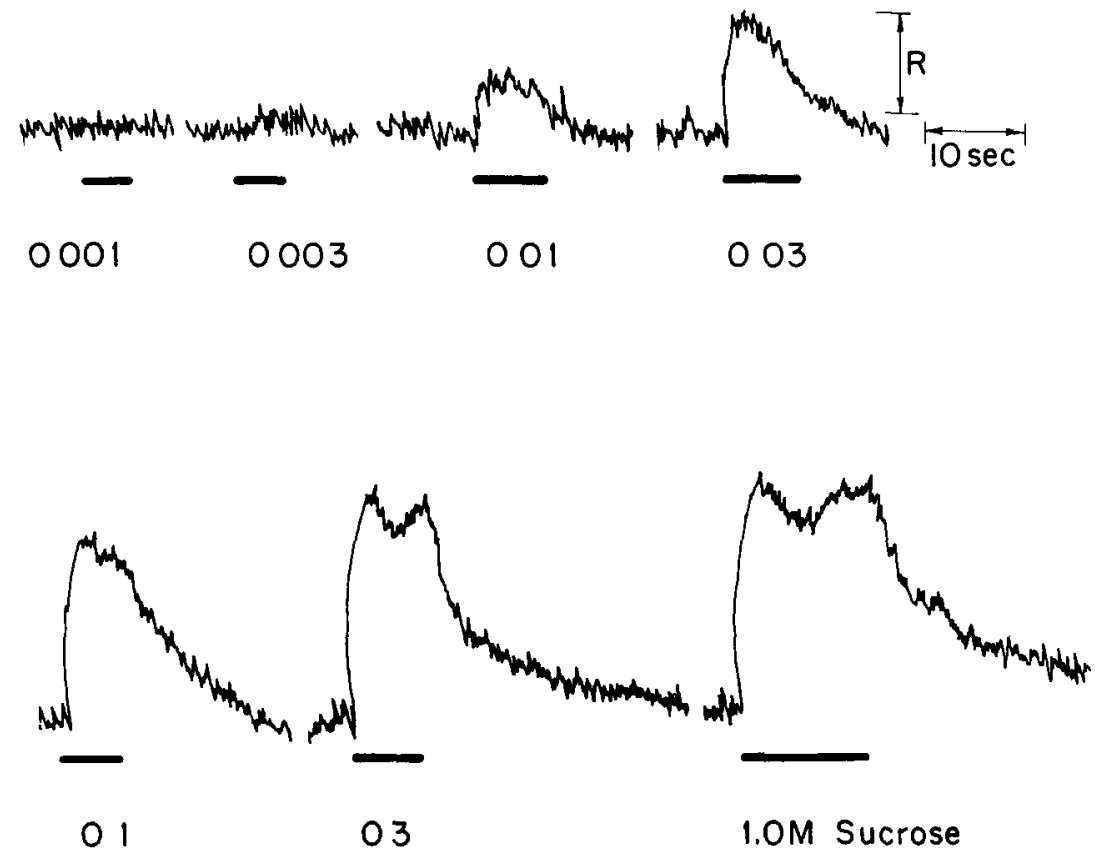

Fig 1 Integrated neural discharge from the gerbil's chorda tympanı nerve in response to a serıes of increasing concentrations of sucrose applied to the tongue The solıd bar under the records indicate stımulus duration, $R$ is the measure of response

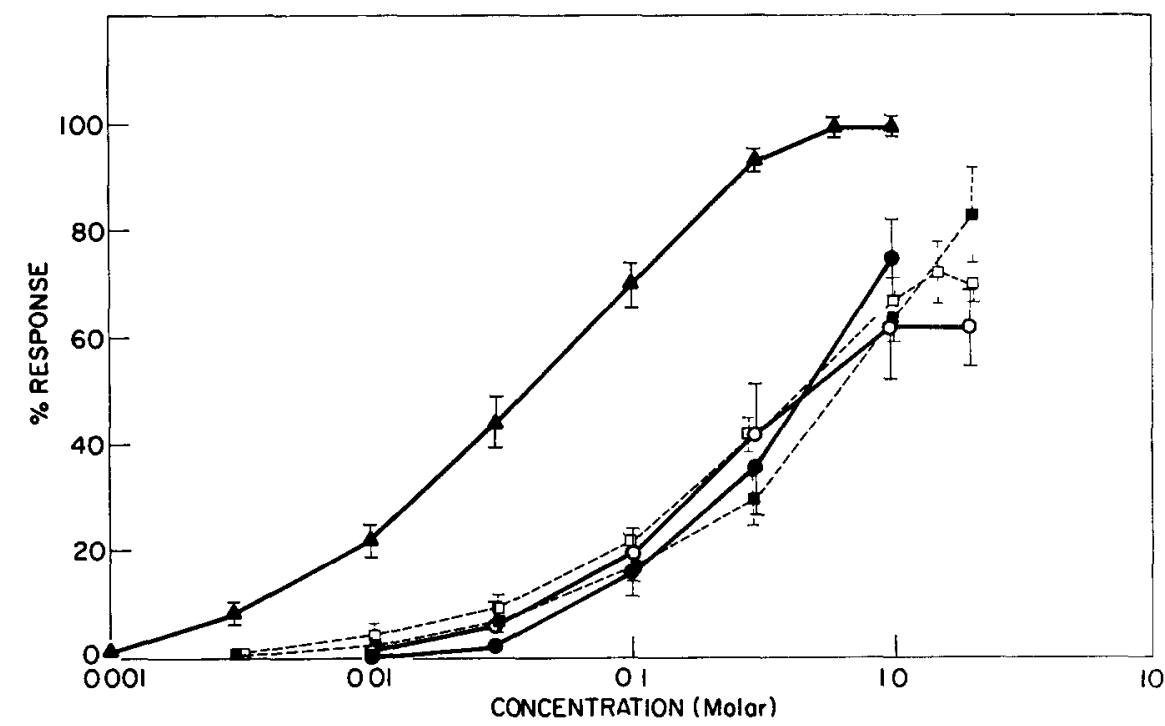

Fig 2 Comparison of mean integrated response of 5 disaccharides as gustatory stımulants The maximum response of sucrose is considered to be $100 \%$ and the response of the other sugars are compared to the maximum sucrose response Sucrose, $\boldsymbol{A}(\mathbf{N}-37)$, maltose, $\square(\mathbf{N}=5)$, maltitol, $\square(\mathrm{N}=5)$, palatınose, $(\mathrm{N}=4)$, and turanose, $\sigma(\mathrm{N}=5)$ Bars indicate $95_{0}^{\circ}$ confidence intervals 
TABIE I

STIMULATING, FHIECTIVENFSS OI SUMF DISAC CHARIDHS (MFAN VALIILS)

\begin{tabular}{|c|c|c|c|c|c|c|c|}
\hline Sugar & Structulc* & $\begin{array}{l}\text { Thresh- } \\
\text { olate+ } \\
\text { molat }\end{array}$ & $\begin{array}{l}C R_{50} \\
\text { imola }\end{array}$ & & $\begin{array}{l}h_{d} \\
\text { (molar })\end{array}$ & $n$ & $\begin{array}{l}\text { Maxmum } \\
\text { 'c pomse }\end{array}$ \\
\hline- & - & & & & -- & & \\
\hline Sucrose & Glu $\alpha(1+-2)$ Fru & 0001 & 0042 & $\pm 0005^{\circ}$ & 0037 & 096 & 10 \\
\hline Turanose & Glu $\alpha(1-3)$ Fru & 003 & 023 & 002 & 030 & 114 & 069 \\
\hline Palatınose & Glu $\alpha(1-6)$ Fru & 003 & - & & 049 & 10 & \\
\hline Maltose & Glu $\alpha(1+4)$ Glu & () 01 & 024 & 1005 & 0) 29 & 100 & $075+006$ \\
\hline Cellobiose & Glu $\beta(1-4) \mathrm{Glu}$ & 001 & & & 033 & 12 & \\
\hline Maltitol & Glu $a(1-x)$ GluOH & 003 & -- & & 034 & 086 & \\
\hline Cellobııtol & Glu $\beta(1->4)$ GluOH & 003 & & & 050 & 127 & \\
\hline Trehalose & Glu $a(1 \leftarrow-1)$ Glu & 003 & 021 & $\dagger 003$ & 026 & 122 & 083 I= 010 \\
\hline Lactulose & Gal jíl 4) Fru & 001 & 018 & .002 & 023 & 098 & $088=008$ \\
\hline$\beta$-Lactose & Gal $\beta(1--4)$ Glu & 001 & - & & 031 & 089 & \\
\hline Melıbıose & Gal $\alpha(1 \rightarrow 6)$ Glu & 003 & 018 & \pm 003 & 037 & 109 & $068 上 027$ \\
\hline Lactıtol & Gal $\beta(1-4)$ GluOH & 001 & $\rightarrow$ & & 026 & 102 & \\
\hline Melıbistol & Gal $a(1-4)$ GluOH & 003 & & & 023 & 100 & \\
\hline
\end{tabular}

* Abbreviations Glu, glucose, Gal, galactose, Fru, fructose, GluOH, glucitol

** Threshold is defined as the lowest concentration tested which elicited a measurable response in $50^{\circ}{ }_{0}$ of the animals (see test)

$n$ - No of molecules per receptor site

$+\mathrm{N}-\mathrm{No}$ of anmals

$\$ 95^{\circ}{ }_{0}$ confidence intervals are indicated

Thirteen disaccharides were tested Three (cellobiose, $\beta$-lactose and palatinose) were not soluble enough to test at high concentrations and 4 (cellobitol, lactitol, maltitol and melibitol) were too viscous to flow through the system at high concentrations The remaining 6 sugars were soluble and not viscous at high concentrations They had concentration-response curves which reached a maximum value (Fig 2, Table I) Frequently, when the maximum had been reached, a highe1 concentration of sugar applied to the tongue resulted in a significantly smaller response This reduced response $\left(5-15^{\circ}{ }_{0}\right.$ less) was not an addptation effect since it occurred regardless of the concentration or recency of the previous stımulus Consequently, high concentrations must have been inhibitory in some way After the maxımum had been obtained at 03 $M$ or $06 M$ sucrose, $25^{\circ}{ }_{i}$ of the animals tested showed a decrease of response Of the other sugars tested a decrease at high concentratıons was never observed in lactulose but was observed in $60^{\circ}{ }_{\circ}$ of the anımals for trehalose, $80 \%$ for melibiose, $80^{\circ}{ }_{0}$ for maltose and $60^{\circ}{ }_{o}^{\prime}$ for turanose All of these sugars except sucrose were tested with $d$ maximum concentration of $20 \mathrm{M}$

The mean response to a sugar plotted on a double reciprocal plot or the Beidler plot (Fig 3A) approxımated a straight line The dissociation constant was determined from the $\mathrm{x}$-1ntercept and the $\mathrm{CR}_{50}$ from the concentration-response curve As seen in Table I there is a close correspondence between the $\mathrm{CR}_{50}$ and the dissociation constant Melibiose was an exception The Hill plot of the data fitted a straight line with a mean slope of nearly one in every case For those sugars in which a maximum re- 


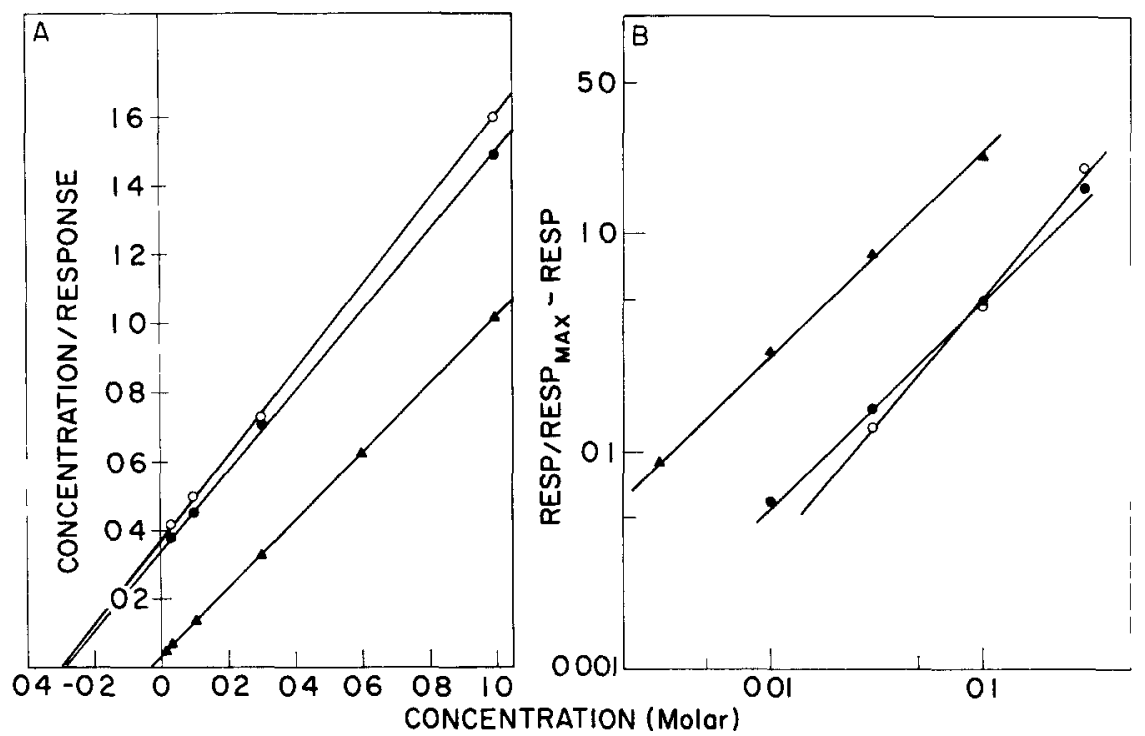

Fig 3 A Beidler plot of data from Fig 2 Resp -- response (height of integrated nerve response) slope is $1 /$ Respmax Respmar being the maximum response and $K_{d} /$ Respmax is the $y$-intercept $K_{t}$ is the dissociation constant and $-K_{a}$ is the $\mathrm{x}$-intercept Sucrose (A), turanose ( 1), and maltose (O) are presented B Hill plot of data from $A$ The slope is $n, n$ being the number of molecules interacting with each receptor site Sucrose, $\mathbf{\Delta}, \mathrm{n}=0$ 96, turanose, , $\mathrm{n}-114$, maltose, $\mathbf{\theta}, \mathrm{n}=100$

sponse could not be attaned the Respmas from the Beidler plot was used

In a comparison of $K_{d}$ values maltose and maltitol were slightly better stimul than the $\beta$-anomers, cellobiose and cellobittol ( $\alpha$-glucopyranosides = $\beta$-glucopyranosides) Reduction of maltose to maltitol resulted in a slightly less effective molecule The same is true of cellobiose and cellobitol The $\beta$-galactopyranoside containing disdccharides, $\beta$-lactose and lactıtol, were generally bettei stımuli than the $\alpha$-anomers, melıbıose and melıbitol ( $\beta$-galactopyranosides $>$ ( $\ell$-galactopyranosides)

\section{DISCUSSION}

In conformity with the results from other mammals, such as the rat ${ }^{17}{ }^{19}$, hamster ${ }^{19}$, two species of macaque monkeys ${ }^{30}$ and the human ${ }^{10}$, the gerbil's sucrose concentration-response curve is sigmoid with a semilog plot Electrophysiologically the gerbil's taste threshold for sucrose $(0001 M)$ is slightly better than that of the hamster $(0005 M)$ and much better than that of the rat $(001 M)$, macaque monkey, (0 01-0 03 $M$ ), human $(002 M)$, calf $(010 M)^{4}$ or squirrel monkey $(001 M)^{30}$ The order of stımulatory effectiveness (sucrose $>$ maltose $=$ lactose) in the Mongolian gerbil, when compared over a single concentration, is geneially consistent with the effectiveness of these disaccharides in other mammals tested For example, as a taste stımulant sucrose $>$ maltose $=$ lactose for both the rat and hamster ${ }^{19}$, sucrose lactose $\geqslant$ maltose in the human ${ }^{10,11}$ and sucrose $>$ maltose. lactose in the $\operatorname{dog}^{12}$

When Beidler ${ }^{3}$ formulated his taste theory he envisioned a single stimulus 
molecule binding to a single receptor site to form a stimulus-receptor comples $\mathrm{He}$ assumed that the integrated chorda tympanı nerve response was proportiond to the number of interactions or complexes formed between the stimulı and the receptor site The data from the gerbil's chorda tympanı nerve response to disaccharides are consistent with this simple monomolecular binding hypothesis because they lit a straight line in the reciprocal plot and have a slope of one in the Hill plot Additional support for Beidler's taste theory was derived from the fact that the $K_{a}$ values whose computation assumes a one-to-one binding mechanism are identical to the $\mathrm{C}_{50}$ which do not depend on this assumption

The present study extends the number of sugars tested electrophysiologically and provides information on sugar-receptor interaction Effectiveness of these $\mathrm{d}$ saccharides as stimuli must be explaned by their different chemical or physical properties

Whether a sugar is reducing or non-reducing probably does not play an important role in stimulation since neither type is necessarily more effective Maltose, cellobıose, lactose, tuıanose, palatınose, lactulose and melibıose are all reducing sugars and are poor stımulı compared to sucrose, a non-reducıng sugar On the other hand. the non-reducing disaccharides maltitol, cellobittol, melibitol, lactitol and trehalose are no more effective than their reducing counterpart

Increasing water solubility has been associated with increasing sweet taste of sugars and their stımulatıng ability ${ }^{2}$ Palatınose, cellobıose and lactose all poor stımuli, are barely soluble compared to sucrose But cellobiose, a poorly soluble sugar, has a lower threshold than its extremely soluble derivative cellobitol By comparison turanose possesses better solubility characteristics than sucrose but is a poorer stimulant than sucrose, therefore, solubility cannot be the sole determinant of effectiveness

The dominant effectiveness of sucrose suggests the presence of a sucrose receptor site The other disaccharides may fit into this same site but not perfectly as witnessed by their fallure to stimulate well A highly specific sucrose site is suggested because the two fructosyl glucosides (the constitutional isomers of sucrose), turanose and palatınose, were much less effectıve stımulı than sucrose Comparison of Drieding models show they are slightly longer than sucrose This may prevent access to the receptor site Unlike sucrose they are reducing sugars, they mutarotate, and exist $\mathfrak{d}$ a mixture of isomers A paucity of one type of isomer which would be complementary to the site could also account for the poor response

Alternately the effectiveness of the disaccharides could be explained by the presence of monosaccharıde receptor sites Sucrose, an $\alpha$-D-glucopyranoside, may be effective because it is binding in a glucopyranoside receptor site The presence of such a site on the blowfly and flesh fly taste receptor cell has been postulated ${ }^{8,27} 35$ Fallure of turanose, palatınose, maltose and maltitol - all $\alpha$-D-glucopyranosides - to be dr effective as sucrose could be attributable to steric hindrance involving the substituents at position $\mathrm{C}-1$ of the glucopyranoside ring A strict anomeric configurational requirement for an $\alpha$-glycoside bond as in fly taste receptors ${ }^{7,13,18} 23$ appears to be absent in the gerbil's taste response Maltose and cellobiose, the $\alpha$ and $\beta$ anomers, respectively. 
ware equal in threshold Maltose is a slightly better stımulant $\left(K_{d}\right)$ An $\alpha$-glucopyranoside receptor site is possible, maltitol, the $\alpha$-glucoside, is a better stimulant ( $K_{d}=$ $034 \mathrm{M})$ than cellobitol $\left(K_{d}=050 \mathrm{M}\right)$, the $\beta$-glucoside Falure of the galactosides to be effective stimulants could be attributed to their fallure to fit the glucopyranoside site well Sucrose could also be fitting into a separate fructose site In this case the substitution of a bulky substituent at C-3 (turanose), C-4 (lactulose) or C-6 (palatinose) of fructose would reduce the effectiveness of the molecule by steric hindrance Sucrose which can be considered a fructose derivative, with a bulky substituent at C-2, is unaffected The 3 fructose containıng disaccharides are reducing sugars, unlıke sucrose, and would exist in solutions as a mixture of furanose and pyranose isomers Should the fructose site require a $\beta$-fructofuranose type of molecule, sucrose would be the most stımulatory

\section{ACKNOWLEDGEMENTS}

This work was taken from a thesis submitted to the Department of Zoology, The University of Michigan in partial fulfillment of the requirements for the $\mathrm{Ph} D$ degree

Supported in part by USPHS Grant NS-07072 to B Oakley

\section{REFERENCES}

1 Andersen, H T , Funakoshi, M , and Zotterman, Y, Electrophysiological investigation of the gustatory effect of varıous biological sugars, Acta physiol scand, 56 (1962) 362-375

2 Andersen, H T, Funakoshi, M , ANd Zotterman, Y, Electrophysiological responses to sugars and their depression by salt In Y Zotterman (Ed ), Olfaction and Taste, Vol I. Pergamon Press, Oxford, 1963, pp 177-192

3 Beidler, L M , A theory of taste stimulation, $J$ gen Physiol, 38 (1954) 133-139

4 Bernard, R A, An electrophysiological study of taste reception in peripheral nerves of the calf, Amer J Phvsiol, 206 (1964) 827-835

5 Cagan, R H, Bıchemical studies of taste sensation I Bındıng of ${ }^{14} \mathrm{C}$-labeled sugar to bovine taste papillae, Blochtm biophys Acta (Amst), 252 (1971) 199-206

6 Dastoli, F R, And Price, S, Sweet-sensitive protem from bovine taste buds isolation and assay, Science, 154 (1966) 905-907

7 Dethier, V G, The physiology and histology of the contact chemoreceptors of the blowfly, Quart Rev Biol, 30 (1955) 348-371

8 Dethier, V G, Evans, D R, and Rhodes, M V , Some factors controlling the ingestion of carbohydrates by the blowfly, Bol Bull, 111 (1956) 204-222

9 Deutsch, E W, and Hansch, C, Dependence of relative sweetness on hydrophobic bonding Nature (Lond), 211 (1966) 75

10 Diamant, H, Funakoshi, M, Strom, L, and Zotterman, Y, Electrophysiological studies on human taste nerves In $\mathrm{Y}$ ZotTerman (Ed), Olfaction and Toste $\mathrm{Vol}$ I, Pergamon Press Oxford 1963, pp 193-203

11 Diamant, H, Oakley, B , Strom, L, Wells, C, and Zotterman, Y, A comparison of neural and psychophysical responses to taste stımulı in man, Acta physıol scand, 64 (1965) 67-74

12 Erickson, R P, Sensory neural patterns and gustation In Y Zotterman (Ed), Olfat tion and Taste, Vol I, Pergamon Press, Oxford, 1963, pp 205-213

13 Evans, D R, Chemical structure and stımulatıon by carbohydrates In Y ZotTerman (Ed), Olfaction and Taste, Vol I, Pergamon Press, Oxford, 1963, pp 165-176 


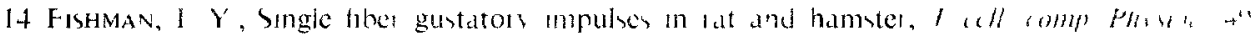
(1957) $319 \quad 331$

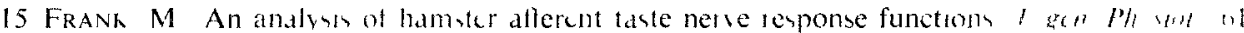
(1973) $588 \quad 618$

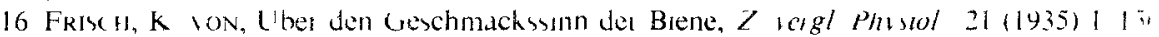

17 Hagstrom, E C AND PFAfFMand C The relativa taste effectiveness of different sugars tol the rat, $J$ comp physol Puchol 52 (1959) 259262

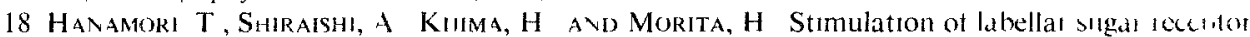
of the leshfly by glucostde, $\angle$ letgl P/lstol, 76 (1972) 115124

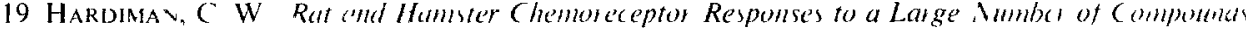

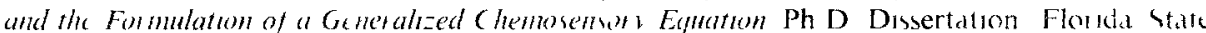
Unir, 1904, Und Miciofinas, Ann Aiboi

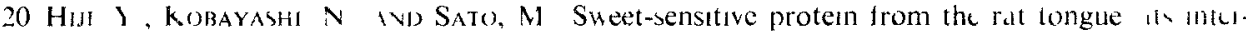
atlon with various sugats Comp Bochcm Phisol, 39B (1971) 367375

21 Hit., A $\vee$ The possible eftects of the aggregation of the molecules of hatenuglobin on its alimo

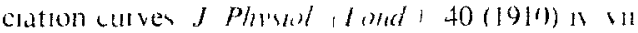

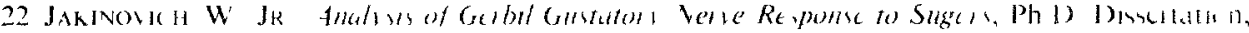
The Unis of Muhigan, 1974 Unas Miciohimes, Ann Aibor

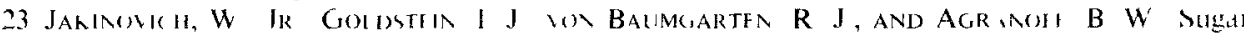

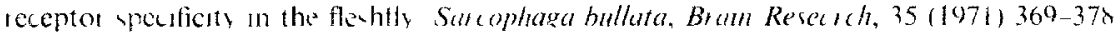

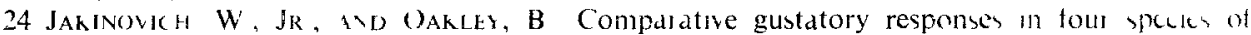
gerbilline codents, $I$ (omp $P h$ shol 99 (1975) 89-101

25 Kur, I B A molecular theory of sreet taste J pham Sol, 61 (1972) 13941397

26 KIMIRA K AMD BEIDLER L M Micioslcutrotestudv of taste receptors of rat and hamister $I$ c(ll comp) Phuvel 53 (1901) $131-139$

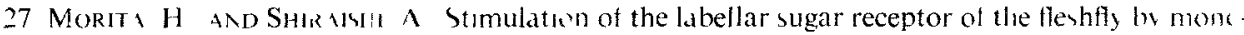

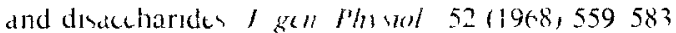

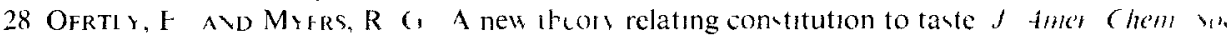
$41(1919) 855867$

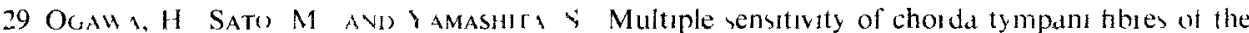
rat and hamste to guntatory and thernal stimuli $J$ Phisol (Lond), 199 (1968) 223-240)

30 Oraw, H Yamasima $\mathrm{S}$, Noma A, avo SATo, M, Taste responses in the Macaque monkey chorda tympani Phisol Behal 9 (1972) 325331

31 O/EKJ M A\D SATO, M, Responses of gustatory cells in the tongue of the iat to stinuli representing the foul taste qualities Comp Brokem Phwsol, 41 A (1972) 391-407

32 Pfafimadn ( Gistaturv nerve impuleses in rat cat and rabbit, $J$ Vearophisol is (1955) 439440

33 Sato, M Yamashita S, 1nd OGalta H Afferent specificity in taste In ( PIATImava (l U) Olfaction and Taste l'ol III Rockefeller Unıv Press, New York, 1969 pp 470.487

34 Shat enberger R S AND ACRFE T E Moleculdi theory of sweet taste. Natule land 2lat (1967) $480-482$

35 Shimada I, Shiraishi A KiJima, H and Morita, H, Separation of two receptor iter in a single labellai sugar receptor of the fleshfly by treatment with $p$-chloromercuribenzodte, $J l i<c t$ Phivol $20(1974) 605621$

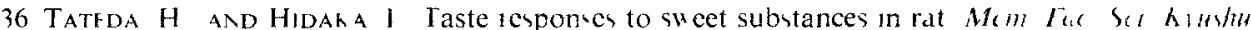

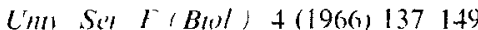

37 Tsuzlik, ) Sweetness and the configuration of sugars Kagaku (Tokio) 17 (19.47) 342340 